\title{
The Role of Administrative and Implementing Law Reforms in Public Administration and Cultural Heritage in Albania
}

\author{
Prof. Assoc. Dr. Alba Dumi \\ Dean of graduated School "Ismail Qemali"Vlora University, Albania \\ Economy Faculty, Management Department,"Ismail Qemali" University, Vlora Albania \\ Economy Faculty, Bussines and Administration Department, Tirana University, Albania \\ Email: alba.besi12@gmail.com

\section{Ma. Borana Koçiu} \\ Economy Faculty, Bussines and Administration Department, Tirana University, Albania \\ Email: bora-vl@yahoo.com
}

\section{Doi:10.5901/mjss.2013.v4n9p82}

\begin{abstract}
The judicial power is one of the important fields of the legal state. As stated in the Albanian constitution, one basic principle is: equality and control between governments. Our paper research will analyze the justice reforms in Albania, will analyze bailiff organizational management (private or state form). This paper identifies and addresses of the important factors underlying of the, bailiff office in Albania and changes in the form of organization, under the administrative and implementing reforms in law. The paper also introduces with the changes in national law, private or state organizational form. This is done in order to seek an independent and impartial tribunal's or court's determination as to whether one's legal rights and obligations are being infringed, and if so, to obtain appropriate compensation and remedy. Civil litigation should be distinguished from criminal litigation. The main difference is that civil litigation is normally undertaken by an individual to seek monetary compensation, to recover properties, or to enforce obligations, while the criminal litigation is instituted in the name of the Government (i.e. the Vlore region Special Administrative Region during 2009-2011years) to suppress crime and to punish criminals.
\end{abstract}

Keywords: Administrative reform, Justice Processes, Law services, State services, Changes in administrative services. JEL Clasification: K0,K12,K22,K23,K40,K42

\section{Introduction}

On jurisprudence, the European Committee of Human Rights decided that, although the European Convention of Human Rights makes no reference to a penal liability of juridical persons, it is not incompatible with such a liability. Consequently, when a penal accusation against a juridical person exists, it has the guarantee of receiving an equitable trial, ensured by article 6 of the European Convention of Human Rights. (Benness 2009) This jurisprudence is in compliance with the orientation of the European doctrine, which estimates that art. 6 and 7 of the European Convention of Human Rights do protect both physical and juridical persons. On the other hand, the Bailiff Section in Albania plays an important role in promoting full compliance with Court and Tribunal of Albania judgments and orders, for example, if a judgment debtor who has been ordered to settle a debt, or a person who has been ordered to vacate premises, fails to do so, application can be made to the Bailiff Section to take the appropriate steps to try to recover the debt or deliver the premises to the applicant. A civil case relates to the legal rights and obligations between two or more persons or institutions. In the event that the parties concerned cannot resolve a dispute themselves, either party may start a civil litigation.

\section{Literature Review and Hypotheses}

\subsubsection{Which is a general concept of administrative law reform?}

To the purposes described above, the project will examine and compare the legal framework regarding Cultural Heritage in four different areas (Europe, Africa, Americas, Asia). 
To this end, four main issues will be taken into account: the definition of Cultural Heritage and cultural property; functions delivered by public administrations; the institutional framework; public and private partnerships instruments. (Blownner A 2009)

About the first issue: the project will consider national legislations and will highlight the legal requirements and criteria according to which cultural objects are identified and regulated.

- About the second issue: the research will focus on the functions carried out by public administrations in this sector.

- About the third issue: the project aims at analyzing the institutional framework existing in the different countries selected.

- About the fourth issue: public and private partnerships mechanisms will beanalyzed from a dual perspective.

When it comes to criminal organized groups even the persons who support, or the ones who know about the group's existence, who accept their rules and agree to help the organization in a criminal act or ensure the necessary materials to commit a crime are sentenced by the Court. Also the attempts for committing a penal act are convicted, even if the attempt has failed and the act is not realized, even reaching in an agreement on doing a penal act is enough to get a conviction, which means that the other person who accepted and agreed to commit the act can be sentenced.The Bailiffs of the Magistrates Court are appointed Officers of the Magistrates Court and as such are required by their office to conduct their duties of office in accordance with the Rules of the Court. Service of all process and execution of matters coming before them will be handled in an ethical manner in accordance with the Court Rules and without favor to any party and in an impartial manner. Service and execution of all process will be attended to without delay and fees charged will be only that which is allowed by law. Multiple attempts at service and execution will be made at no additional cost to the client, so as to effect service/execution or until it can be confirmed that the matter cannot be bought to conclusion.

\subsection{Specific Objectives in this paper research}

\subsubsection{H 1: What is quality of governance and how can this quality be advanced in multifaced national and international governance processes and structures?}

Governance concerns the involvement of public (and private) actors to address social problems, including policy-making and implementation. Quality refers to a diversity of values, including the ethics and integrity of governance. Other criteria refer to the rule of law, democracy and legitimacy, and effectiveness of governance.

Topics of this paper research is to be explored include:1.Quality of Governance: Good Governance in Context Good governance as managing public values good and well, law and integrity, in politics and administration, relating elite and street-level values and involvement.2. Good governance policies, systems, instruments, leadership.Many initiatives to improve the quality of governance are proposed or present. 3. Quality of Governance Organization and Relations. The relationship between quality of governance and the structure of governance (including centralisation-decentralisation; public private partnerships, the involvement of civil society and third sector organizations). 4. Quality of Governance and Governance Studies: theory and methodology.

Reflection on the state of the art in this field paying extra attention to theoretical and methodological advancement, including the aim to stimulate comparative international research. (Blownner A, Hozel S. 2009)

The European Union through the definition of organized groups tried to give the notion of organized crime. According to the common plans of the countries of the European Union, in 21 December in 1998, a criminal organization would be; the organization that has a structure made from two or more persons that is created to act during a certain period and that commits crimes that can be sentenced at least four years or more by the law. And this is how the Penal Codes of different countries gave the definition of "organized crime".A full Affidavit of Service or a full Report as to non service/execution will be returned to the parties concerned outlining the reasons that the matter could not be served or executed and suggesting alternative actions that can be enforced in accordance with the Rules of the Court. (There is no cost for an Affidavit of Service or written report to an action).Points to consider, assist with prompt and effective service of process.

\subsubsection{Which is a general concept of administrative court service?}

Process that requires service, after being filed and sealed by the Court of issue, should be forwarded to the Bailiffs Office 
(Albania Bailiffs Office) or to the Bailiff of the Magistrates Court District where the party to be served can be located. In Albanian region the bailiff offices are Execution must be defined and supported by a clear legal framework that defines the powers, rights and responsibilities of the parties.

\subsection{Administrative Management and Administrative Services.Correct address of service.}

[1] Ensure the address of service is correct and complete and if the action is hand written, all details are legible.[2] Include with the process a note giving any information that may assist in the speedy location of the person to be served, such as: Directions to the address of service, if the address is known to be difficult to locate.[3] Information, if known, as to when is the most likely time to find the Defendant at a given address.[4] Any information that may assist the bailiff to locate the defendant without undue delay. The Bailiffs Office organizes service of process on a daily basis, covering all Court Districts within the greater and surrounding areas.[5] [6] [7] Process for service will be attempted within 24 hours of receipt and if not served further attempts will be made at various times day and night until service is effected or it is confirmed that service can't be accomplished by normal means.

Normally service is affected and the completed affidavit of service is returned to the Plaintiff within working days. Bailiffs' service fees may be $p$ aid at the Bailiffs Office by cash or $c$ during business hours or if process is sent by post a tax fee or Money Order made out to "Bailiffs Office" should be enclosed with the process. A receipt for fees will be returned to the person lodging documents. Service documents for service, in the same Court District where the documents are filed, may be left at the Court with the appropriate service fees in a sealed envelope for collection by the Bailiff sector.[8] [9] [10]

\subsubsection{H 2.The Bailiffs Office organizes service of process covering all Court Districts within the greater surrounding areas.}

The person who has obtained a court decision or as it's called the creditor, in order to materialize his right must in accordance with : Article 515 of the Code of Civil Procedure, choose one of two services the public one or the private bailiff service, in addition the creditor shall provide a) Executive title (original or notarized and b) execution order only in original also the payment of the fee issue in the execution, which will be returned to the person lodging documents and only where is appropriate, the person's attorney, who represents the creditor party.

\subsubsection{General functions and Administrative compatibility.}

Constitutional Albanian Court obliges the institutions to pay reparations and money back to employees Bailiff Office and legal institutions will need to make better accounts before dismissing their dependents. There are innumerable cases where employees wander through the doors of the courts to obtain redress unfair break from work and after he won the trial must wait for months until receiving the money. But a decision last days of the Constitutional Court is likely to end this practice. The Court had to examine a typical case to come from the city of Portland for which has come to the conclusion that the unreasonably long judicial issue in these cases as well as time of employees that have earned this right by a court decision is a violation of the Constitution.

In most cases, the indemnity institutions drag their former employees on the grounds of limited funds. Based on this fact, in a given decision in the case Constitutional states that lack of funds can't be used by institutions as an argument for profitable of the debt of employees if the court concluded that he was dismissed from work without the right.[11] [12] [13]

\subsection{Democracy and Public Administration, foreign experiences}

The issues of 'democracy' and good public administration or 'good governance' have largely been decoupled in theory and practice. This may be for several reasons - divisions between scholarly communities; 'real politik' in intergovernmental organisations; the Webberian idea that 'bureaucracy' is a relatively discrete phenomena; etc. Whatever the reasons, it is clear we do not know enough about the following questions:

- In the early 'western' transitions to democracy (in Europe and North America), what was the inter-relationship between this and the rise of 'progressive public administration'? 
- Did public administration go through a qualitative transition in parallel with the democratic transitions in political systems?

- If so, what is different about PA under democratic and non-democratic political regimes?

Similar questions can be asked about many countries transitioning from colonial, authoritarian, military, communist and other non-democratic regimes. The purpose of the proposed 'Democracy and Public Administration (DPA) Study Group' is to explore these issues. We do not expect to be able to definitively answer them all, but at a minimum to be able to establish what we already know and what remains to be discovered - i.e. develop a research agenda and community to take this beyond the term of the Study Group.

\subsection{Albanian justice and European Convention of Human Rights}

State authorities can not cite lack of funds as an excuse for not respecting a financial obligation that comes from a court decision, cited in most of the arguments with which the Court justifies its decisions. The event that has set in motion the Constitutional Court dates back to the city of Albanian region. In spring 2008 a citizen of the Inspectorate dismissed the National Urban Construction district court addressed the claim that during her discharge violated procedures are provided in the Labor Code. Court decides in favor of former employee forces to indemnify him in five months' salary and a bonus for seniority for a period of six months and a half. After receiving the execution order of execution of some office notes that they could not impose Urban Construction Inspectorate to pay the fine and issue passes bailiff's office in Tirana. [Albania Civil Code, USAID and MOJ, year 2010 pp 23, 24, 26]

Set the excessive length of judicial proceedings in violation of the European Convention on Human Rights and the rejection of the argument of lack of funds to indemnify the employee is considered a support to hundreds of individuals who continue to wander through the doors of the courts, and a message clear to the judicial power to court proceedings concluded in time. According to the Albanian Court, the lack of money can't be used as an argument by the institutions not to pay damages to workers unjustly dismissed from work. ( For example: Review of the case has as starting point a judicial process in some Albanian offices where worker sue the institution for two years but with time could not obtain indemnity. The court had decided to pay indemnity to the employee for five violations of the provisions of Labor Code during its break from work. Unreasonably long judicial processes or the implementation of the decision of the court regarded as violation of right to a fair trial by prejudice to the Constitution EU calls on all political parties to urgently proceed with the appointment of a new people treatment. [Albanian Civil code year 2008, pp123]

\subsubsection{H3.EU stalemate is hampering the work of institutions for private and public sector.}

The escalating political situation in the country which brings delay in undertaking important reforms to the country viewed with concern by representatives of the European Union Delegation in Albania. In a response of EU delegation notes the absence in the operation of some institutions because of the political stalemate. Among these institutions, the changed stated (public and private sector and its function) that because of the dispute is not doing its replacement with a new name.

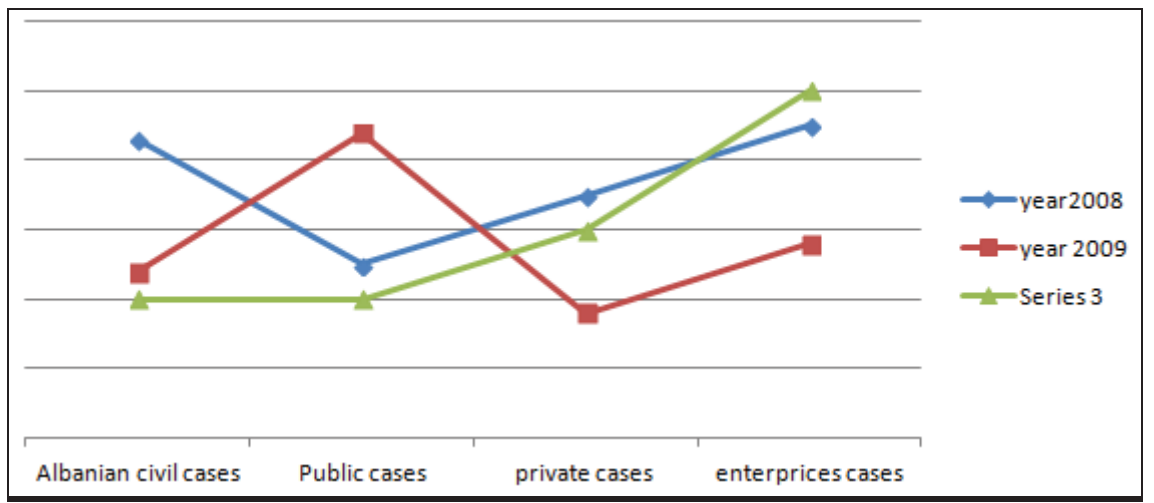

Grap.1: The indicators of distribution cases by bailiff general office. [Series 3 is showing the advantages of private bailiff sector under EU suggestions.] 


\section{Improving Information and Methods in the Collection Process}

The procedural code and insufficient resources in the courts create problems in collecting court judgments. The Systems for Enforcing Agreements and Decisions (SEAD) Program will support the efforts of government and legislators to improve legislation; the ability of courts to gather information from other government agencies, from debtors, and from third parties; and to bring new vigor to court orders. The SEAD Program will also work to improve working methods within courts so that cases, orders, and information are better used. The Bailiffs Office, within the jurisdiction of any district court of first instance make the local level of organization and administrative subordination of the General Directorate Normally service is affected and the completed affidavit of service is returned to the Plaintiff within 15 working days. Bailiffs' service fees must be paid before execution of the decision began as a fundamental condition to layd down by:

Article 515 "Putting in execution [Amended by Law No. 10 052, dated 29.12.2008 Article 17]

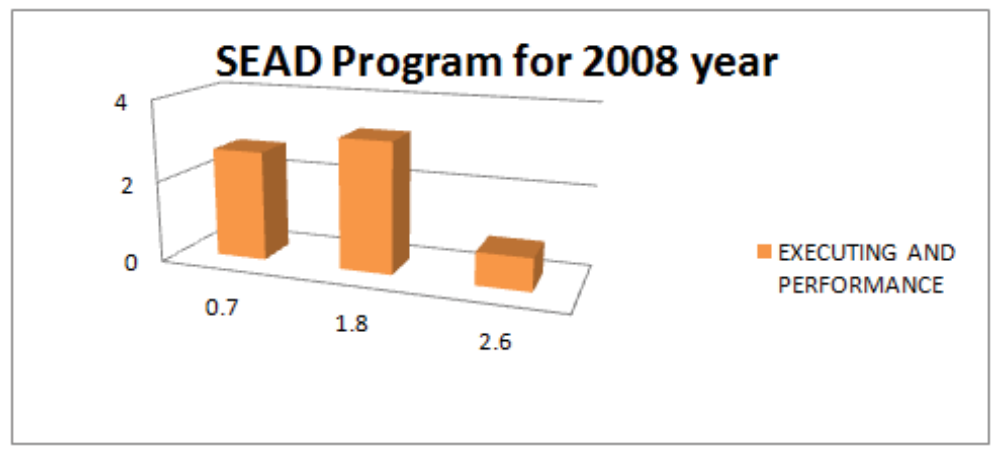

Tab 2. Amended by Law No. 10 052, dated 29.12.2008 Article 17

The execution order is executed by the bailiff service, public or private, by a bailiff, at the request of the creditor. The creditor, in addition to execution, you must submit:

a) Executive title (original or notarized);

b) execution order (original);

c) payment of the fee issue in the execution;

d) where appropriate, the person's attorney, who represents the creditor party"

A receipt for fees will be returned to the person lodging documents.

When not properly fulfilled the above documents for executing the order of execution, the bailiff leaves the applicant a 5-day deadline for filling the gaps. When the applicant does not meet these deficiencies within the prescribed period, the documents returned to him. When shortcomings are avoided in due course, demand for executing considered registered by the date it is submitted to the bailiff. Putting in the execution of an enforcement order is made within 15 days from the date of submission of the creditor. [Amended Law No 10052, Article 17]

\section{Methodology and Results}

The highlight the key results and conclusions from the empirical studies, evidence or experiences presented; it ensures that results are clear, precise and justified. In this paper is analyze the Albanian reforms under developing government reforms. The methodology of this research is creating the frame conditions for innovations and institutional system of innovation. The proposed definition of the field of entrepreneurship is complex, as is the phenomenon itself. It's of interest only if it allows researchers to reach a minimum level of consensus on what the field is and is not. We are using correct data that are analyzing on statistical and analytic models. The data are gathering by programs and projects that are implementing in Albanian region under developing government reforms

For the first time (1995) since the transition, Albanians did not consume as much as they produced. In 1992, consumption and investment were nearly twice (1.9) as high as GDP, with investment accounting for only 4-5\% and mainly from the state sector. By 1995, consumption and investment were only 1.2 times as high as GDP, with investment accounting for $20-21 \%$ of GDP. Indeed, total savings for 1995 were estimated at $24-25 \%$ of GDP, compared to $22 \%$ for 
the European Union.

The above mentioned Strategy constituted the basis for the simultaneous preparation of the first Report on the Environmental Situation in Albania and the National Environmental Action Plan (NEAP). These documents constituted the first effort in bringing together development and environment in Albania. The impact of all economic activities on the natural environment was considered and the most affected zones were defined according to the economic activity origin of the environmental damage. The NEAP provided the basis for future actions of the different institutions and organisations which are obliged to take into account environmental considerations in their development plans

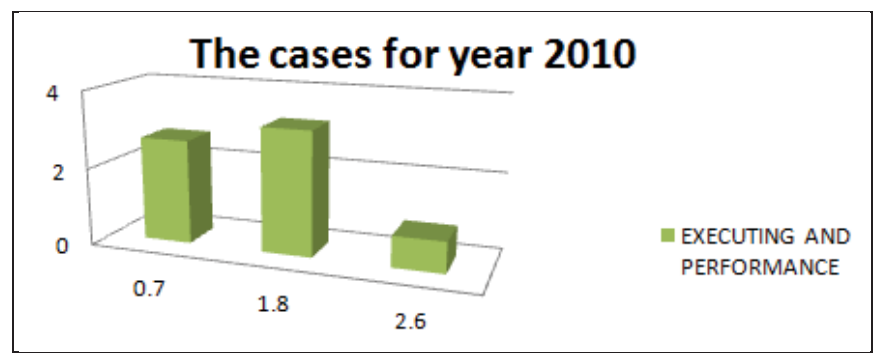

Tab 1.The distribution of executions of an enforcement order, year 2010, Albania Region

\subsection{Development of Hypotheses}

\subsubsection{Public Sector Reforms in the 21st Century'.}

The main objective of the study group is to map and compare the reform agendas of national states between different regions of the world in the beginning of the $21^{\text {st }}$ century as they unfold under the pressures of globalization. In this century, national states will be confronted by increasingly globalized problems, such as climate change, transnational migration, terrorism, economic inequalities, and the financial crisis. Although the challenges are the same, the responses in terms of reform agendas will be very different.

Western European countries are faced to constraints imposed by the international crisis, and some of them are trying to resist against the assault on the Welfare State machine; the agenda thus tends to protect their bureaucracy that has been transformed in the last quarter of $20^{\text {th }}$ century. In other regions, or for emerging economies, there is a movement towards an expansion of the State machine, in a context marked by an unfinished agenda of reforms - here the agenda needs to focus on reforming bureaucracy and the search for results.

This paper research aims at improving and strengthening the capability of public administrations to protect and to enhance Cultural Heritage, as a key factor for boosting state, regional and local attractiveness, economies for contributing to sustainable development.

At this end, it seems important to share and to compare the experiences of regulatory actions enacted in order to guarantee cultural heritage safeguard and improve its fruition and knowledge as of direct- action State, regional and local authorities have undertaken to this purpose. Many of these tools proved hard to handle and seem to claim further and more exhaustive reflections and studies.

Especially difficult has been, in a lot of experiences, implementing effective models of partnerships between public and private cultural sector actors, despite the emphasis put on privates involvement in Cultural Heritage Enhancement.

In article( 394-a-) it is clearly expresses that the founder or creator of a terrorist group, band or organization who aims penal acts such as murders, kidnapping, damaging public objects like transporting vehicles, infrastructure or information systems, this article also foresees punishment for the individuals or groups who aim to steal airplanes, who produce, posses and sell nuclear weapons, biologic, chemical or any other sort of weapons and dangerous materials, also the distribution of radioactive materials, toxic substances, individuals that may cause fires or explosions, damage water-supplies, energy-supply or any other fundamental resources, and aiming to frighten citizens and to put at risk the constitutional regulations of the country or the interests of international unions. 


\section{Conclusions and recommendations}

Albania Government worked with donors on the public financial management agenda by strengthening core public financial management units (Ministry of Finance, Supreme Audit Institute, Procurement Directorate within the Office of the Prime Minister) as well as the financial management units within each line agency (e.g., budget departments within line Ministries). On matters relating to public sector human resource management, the reform strategy envisaged addressing this issue in two major stages: civil service reform and broader public sector human resource management reform. During the stage, the reforms aimed to create the managerial and professional nucleus required to lead any serious efforts to improve the accountability and performance of public institutions.

Different policies against organized crime must be part of the engagement of all the societies and must aim the prevention and the control of this sort of crime. The penal legislations must involve the newest forms of organized crime from time to time, especially those related to human traffic and cyber crimes, because even though in our country they are not very developed, they remain very dangerous and harmful acts. Another important issue is the implementation of the penal legislation which has a major importance in the prevention and in an effective fight against the organized crime.

\section{References}

Penal Code of the Republic of Macedonia; Publish 2000 year

Penal Code of the Republic of Albania; Publish 1999 year

A. Dumi, General knowledge of the economy and ADP, Publish January 2012,

A Dumi, MJSS Journal 2012 Vol 3 Nr 3 "Albania and Development law"

A.Jashari, Commercial law subjects, Tetovo, 2008

I.Zejneli, Criminal law- special part- lectures, Tetovo, 2007

R. Halili, Criminology, Pristina, 2009

V.Latifi, Criminology, Pristina, 2008

S.Begeja, Criminology, Tirana, 2004

M.Kancev, Kazneno pravna zastita na ekonomskite odnosi, MPKK, nr.1, Skopje, 1997

Sh.Milan, Organizovani crime-Pojam of krivicnoprocesni aspect, Belgrade, 2003, CPC Article 316.CPC Articles 321 and 322.

4 Justice and Home Affairs Council Conclusions of December 6-7, 2007, Council doc.15966/07, Presse 275, p.21

Convention on the Prevention of Terrorism Art.26(3) stating that "parties which are members of the European Union shall, in their mutual relations, apply Community and European Union rules in so far as there are Community or European Union rules governing the particular subject concerned and applicable to the specific case".

See also the Declaration formulated by the Community and Member States upon the adoption of the Convention, where it is stated that the objective of the insertion of a disconnection clause is to take into account the institutional structure of the Union when acceding to international Conventions.

See comment by Tony McNulty, then a Home Office Minister, to the House of Commons European Scrutiny Committee, 26th Report (session 2007-08), para.26.3.CPC Article 340. Civil Procedure Code, Section $173 \mathrm{dh}$ ).

CPC Article 364 Commentary of Criminal Procedure; Halim Islam, Artan Hoxha and llir Panda, Tirana 2003, p. 489.

Civil Procedure Code, Article 236. CPC Article 341. United Nations Convention on International Organized Crime (Palermo Convention), adopted on 12-15 December 2000.

DNB (2002): "Structure of Financial Supervision," Quarterly Bulletin of de Nederlandsche Bank, March, 37-42. DOWD, K. (1994): "Competitive Banking, Bankers' Clubs, and Bank Regulation," Journal of Money, Credit \& Banking, 26, 289-308.

EC (2001): "Towards an EU Directive on the Prudential Supervision of Financial Conglomerates," Brussels: European Commission.

EDWARDS, F.R. and M.S. CANTER (1995). The Collapse of Metallgesellschaft: Unhedgeable Risks, Poor Hedging Strategy, or Just Bad Luck?, Journal of Applied Corporate Finance 8, 86-105. 